\title{
Foundation Phase teachers' experiences with instruction in the mother tongue in the Eastern Cape
}

\begin{tabular}{|c|c|}
\hline \multicolumn{2}{|c|}{$\begin{array}{l}\text { Authors: } \\
\text { Madoda Cekiso }{ }^{1} \text { (D) } \\
\text { Thenjiwe Meyiwa }^{2} \text { (D) } \\
\text { Mashudu Mashige }^{3} \text { (D) }\end{array}$} \\
\hline \multicolumn{2}{|c|}{$\begin{array}{l}\text { Affiliations: } \\
{ }^{1} \text { Department of Applied } \\
\text { Languages, Tshwane } \\
\text { University of Technology, } \\
\text { Pretoria, South Africa }\end{array}$} \\
\hline \multicolumn{2}{|c|}{$\begin{array}{l}{ }^{2} \text { Office of the DVC Research, } \\
\text { University of South Africa, } \\
\text { Pretoria, South Africa }\end{array}$} \\
\hline \multicolumn{2}{|c|}{$\begin{array}{l}{ }^{3} \text { School of Human and Social } \\
\text { Sciences, University of Venda, } \\
\text { Thohoyandou, South Africa }\end{array}$} \\
\hline \multicolumn{2}{|c|}{$\begin{array}{l}\text { Corresponding author: } \\
\text { Madoda Cekiso, } \\
\text { cekisoMP@tut.ac.za }\end{array}$} \\
\hline \multicolumn{2}{|c|}{$\begin{array}{l}\text { Dates: } \\
\text { Received: } 20 \text { Apr. } 2018 \\
\text { Accepted: } 03 \text { Oct. } 2019 \\
\text { Published: } 25 \text { Nov. } 2019\end{array}$} \\
\hline \multicolumn{2}{|c|}{$\begin{array}{l}\text { How to cite this article: } \\
\text { Cekiso, M., Meyiwa, T. \& } \\
\text { Mashige, M., 2019, } \\
\text { 'Foundation Phase teachers' } \\
\text { experiences with instruction } \\
\text { in the mother tongue in the } \\
\text { Eastern Cape', South African } \\
\text { Journal of Childhood } \\
\text { Education 9(1), a658. } \\
\text { https://doi.org/10.4102/ } \\
\text { sajce.v9i1.658 }\end{array}$} \\
\hline \multicolumn{2}{|c|}{$\begin{array}{l}\text { Copyright: } \\
\text { (C) 2019. The Authors. } \\
\text { Licensee: AOSIS. This work } \\
\text { is licensed under the } \\
\text { Creative Commons } \\
\text { Attribution License. }\end{array}$} \\
\hline \multicolumn{2}{|c|}{ Read online: } \\
\hline 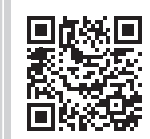 & $\begin{array}{l}\text { Scan this QR } \\
\text { code with your } \\
\text { smart phone or } \\
\text { mobile device } \\
\text { to read online. }\end{array}$ \\
\hline
\end{tabular}

Background: The perception that educating learners using their mother tongue contributes positively to educational and learning outcomes is well documented.

Aim: This study explores the purported benefits of employing the mother tongue in teaching Foundation Phase (FP) learners. Specifically, the study focuses on an examination of the experiences of teachers of isiXhosa (one of the indigenous languages in South Africa) and explains the effects of employing isiXhosa in teaching at the FP (Grades 1-3).

Setting: The study was conducted in three rural schools in the Eastern Cape.

Methods: The study utilised a qualitative approach and case study design was followed. The sample comprised nine FP teachers (one male and eight females) who were selected purposively from three public schools. Three FP teachers were selected from each school and the one-onone interview was used to collect data. The collected data were analysed thematically.

Results: This study revealed that a majority of FP teachers had not received training to teach subjects using isiXhosa as a medium of instruction. This study also revealed that teachers encountered numerous difficulties in teaching mathematics and life skills using isiXhosa as a medium because of lack of vocabulary to match mathematics and life skills concepts.

Conclusion: The authors suggest that teacher training institutions should provide adequate and relevant professional training to FP teachers so that they could teach in isiXhosa optimally. The authors also suggest that all textbooks, readers, educational media, study guides and related literature be made available in isiXhosa.

Keywords: South Africa; mother tongue teaching; teacher experiences; teacher training institutions; mother tongue based education.

\section{Introduction}

The end of apartheid in South Africa ushered in democracy, which led to the country adopting a multilingual policy. The policy declares 11 languages as official, that is, nine indigenous languages and English and Afrikaans, a southern African language derived from a form of Dutch brought to South Africa by Protestant settlers in the 17th century. Hence, the language-in-education policy in South Africa stipulates that all learners have a right to be taught in their mother tongue from Grades 1-3.

Subsequently, the perception that educating learners using their mother tongue contributes positively to educational and learning outcomes is well-documented (Begi 2014; Kuper 2003; Malone \& Malone 2010; Njoroge 2017; Prah 2009; Trudell 2005; UNESCO 2006; Wigglesworth \& Simpson 2008; Young 2009). It is for this reason, among others, that the South African languagein-education policy grants official status to the 11 major indigenous languages of the country. In an attempt to develop these languages and improve the process of learning and teaching, the policy stipulates their use for Grades 1-3 (Foundation Phase [FP]). The foregoing view is predicated upon the premise that the benefits of learning in the mother tongue in primary school education are likely to lead to improvement in learners' academic performance, largely because of the belief that learners are being taught in a language they understand. Benson (2004) avers that because children already speak their mother tongue when they come to school, they can invariably learn to associate sounds with the symbols they see, thus facilitating understanding. However, the lexical capacity of indigenous languages to effectively convey modern science and technology has been questioned, which has also put in doubt the effectiveness of indigenous languages in classroom instruction (Gacheche 2010). In addition, Prah (2009) asserts that critics of instructions in the mother tongue highlight the fact that local languages have limited geographical reach, and 
lack standardisation as well as orthography. Prah (2009) further contends that:

$[A]$ language that is used as a medium of instruction should meet the following criteria: it should be considered suitable by users and worth the effort to acquire; it should be teachable to the required standard with sufficient resources for its dissemination; and it should be experienced in use in a natural, informal, undirected language environment such as the home. (p. 9)

Prah's second criterion, that is a language should be teachable to the required standard with sufficient resources for its dissemination) - from the criteria listed hitherto- is the major focus of this study. Benson (2004:156) submits that in developing countries, mother tongue-based education can only be effectively operational where basic learner needs are being met. Obanya (2004) defines mother tongue or first language as the language transmitted by the family as members of the indigenous language community in a given geographical-linguistic environment. In the context of this article, mother tongue learning refers to a native Xhosa learner, who is brought up in an ideal Xhosa rural environment in the Xhosa-dominated province of the Eastern Cape in South Africa, and uses isiXhosa during all social interactions (Obanya 2004), formal and informal. It is our considered view in this context that a well-trained teacher providing instructions in the mother tongue is one of the learner's basic needs, particularly in the FP. Smit (2001) argues that in the process of learning and teaching, the focus on teachers is important as they are key role players in implementing the language policy. She further argues that despite this, teachers' voices are seldom heard when a new language policy is planned in South Africa notwithstanding the important role they play in the interpretation and enactment of an education policy change. It is in the light of the foregoing that we set out to investigate the teachers' experiences in using the mother tongue (isiXhosa), in this instance, as a medium of instruction in the FP. The assumption we make is that teachers' experiences are essential towards shedding some light on whether isiXhosa language has the potential to be used successfully as a medium of instruction for subjects in the FP with positive outcomes. To this end, the study envisages to provide some insights on what is taking place in the classroom with regard to the use of isiXhosa as a language of learning and teaching (LOLT). It is our view that gaining such insights is likely to enhance teachers' choices in selecting teaching methods and strategies that will contribute towards documenting and analysing their experiences in selected primary schools of the Eastern Cape. Accordingly, this study is underpinned by an attempt to answer the following research questions:

- How does teachers' professional training assist in teaching in the medium of isiXhosa?

- How does the available material in isiXhosa assist teachers in the teaching process?

- What challenges do teachers encounter in teaching Maths and life skills in isiXhosa?

- What methods and strategies could be put in place in order to make teaching in isiXhosa effective?

\section{The benefits of teaching in the mother tongue}

While there are several factors that are involved in the process of delivering quality basic education, language is, without a doubt, key, because it is the medium for communication and understanding in the classroom (Benson 2004). Parry (2000) holds the view that the use of the mother tongue for imparting instructions facilitates the child's acquisition of a second or third language and understanding of the cultures attached to the languages. The World Bank (2005) buttresses this view by arguing that using a mother tongue as a medium of instruction often leads to inclusion of more local content in the curriculum, which makes the educational experience more relevant for learners.

Available research studies provide evidence that a curriculum based in a language known to the child, and a familiar culture and environment, as well as localised and locallydeveloped texts has a determining effect on early learning success (Mackenzie \& Walker 2013).It is to this end that Gacheche (2010) asserts that mother tongue based education can locate primary education contextually and allow improved epistemic access to local communities, which are often minoritised and marginalised. The notion of mother tongue based education has been examined by a number of researchers, who generally agree on the following benefits: it improves reading and learning outcomes; facilitates learning a second or foreign language; improves internal educational efficiency; improves children's self-concept and identity and improves local culture and parental involvement (Ball 2008; Bender et al. 2005; Smits et al. 2008; UNESCO 2007, 2011). Supporting the beneficial effects of education in the mother tongue, Colliers and Thomas (2004) argue that literacy in a child's native language establishes a knowledge, concept and skills base that helps transition from reading in the native language to reading in a second language (L2). Further, this notion is supported by Cummins (1989) who states that if a child has a strong foundation in literacy skills in his or her own language, those skills can be transferred using the L2. According to Martin (2005), there is evidence that mother tongue based instruction assists poor rural and poor urban working class learners to get access to languages with global and wider reach, and languages with wider socioeconomic mobility.

The literature on using a mother tongue as a medium of instruction, in order to improve quality of education and learner success, emphasises the logistical problems of making this ideal a reality (Murray 2007). The results of a study conducted by Murray (2007) on instruction given using the mother tongue reveal that whatever language is used for instruction does not make any difference, what matters is to equip the teacher with the necessary skills and materials. This finding is based on the premise that Murray observed that some learners who were privileged to have been taught using the mother tongue as a medium did not display stronger literacy skills than their counterparts who did not have the same experience. However, Benson (2004) argues that merely changing the language of instruction in the 
absence of the political will to change the status quo in a country will not bring about any meaningful impact on the achievement of teaching and learning goals. Therefore, within the South African educational spheres where the mother tongue is used as a medium of instruction, it is necessary that more research be conducted to know the benefits of instruction in the mother tongue and other factors that contribute towards improving educational outcomes. Equally necessary are kinds of research that seek to document and analyse teachers' experiences in using mother tongue as a medium of instruction.

\section{Teachers' experiences in using the mother tongue as a medium of instruction}

Despite the growing literature on educational change and policy change in general, not much research has been directed towards documenting the experiences of primary teachers and policy change in relation to developing countries, South Africa included (Smit 2001). The available literature reveals that teachers' proficiency in the language of instruction and the pedagogy of learning and teaching through a mother tongue is a critical issue (Makeleni \& Sethusha 2014; Muthivhi 2008; Smit 2001). This idea is supported by Harlech-Jones (in Murray 2007) who points out that lack of proficiency in the medium of instruction, whether it applies to teachers or learners, will negatively influence the success of the learners. Chihana and Banda (2013) conducted a study on the nature of challenges teachers encounter when introducing a mother tongue literacy course in Grade 1 in Malawi, and their findings revealed that the nature of challenges was related to language of initial literacy teaching and learning, learning material and methods and teacher training in using mother tongue as medium of instruction. The results further revealed that despite the fact that the course had very good features and strategies that could help teachers to teach initial literacy effectively, the conditions in which the course was implemented were unfavourable. In a South African context, Matjila and Pretorius (2004) argue that both learners and teachers struggle with literacy in the African languages. Benson (2004) states that as long as there is no specific training on multilingual strategies, instruction will be ineffective.

The literature on mother tongue education often points to the lack of instructional materials, which works against transmission of content in local languages (Gacheche 2010). According to Prah (2009), this lack of material is habitually blamed on the abundance of languages in African countries, making it difficult to publish in all of them. Prah, therefore, recommends the standardisation of African languages to ease the production of learning materials in the mother tongue. Muthivhi (2008) conducted a study on Grade 1 teachers' experiences on using the mother tongue (Tshivenda) as a learning medium of instruction and its efficacy in enhancing learning and development. The results of her study indicated that the fact that the language of instruction was the teachers and learners' mother tongue did not seem to help in improving the quality of learning and teaching. This is due partly to the fact that the teachers were experiencing challenges related to both teaching methods employed and the use of language as an instructional medium. Thus, while studies and policies continue to support the use of mother tongue as a medium of instruction in the FP, it is also of great importance to document the teachers' experiences in implementing such policies.

\section{Research method Design}

This article is based on a study that was carried out in the East London District of the Eastern Cape Province. The focus was on rural public schools. A qualitative research approach was followed in the study. Persuaded by Slavin's (2007) notion that qualitative research pre-occupies itself with the lived experiences and perspectives of participants, the researchers sought to focus on the experiences of teachers regarding the use of the mother tongue for epistemic access. The study also used a case study design which Bromley (1990 in Maree 2007:75) has called 'systematic inquiry into an event or a set of related events which aims to describe and explain the phenomenon of interest'. Therefore, a case study was deemed relevant for this study, which sought to explore the teachers' experiences in using isiXhosa as medium of instruction in the FP.

\section{Participants}

With the focus on the experiences of the FP teachers on the question of using isiXhosa as a medium of instruction, the sample consisted of nine FP teachers (one man and eight women) who were purposively selected from three public schools in East London. Three isiXhosa speaking teachers of the FP from each school participated in the study. Their ages ranged between 29 and 55 years and their experiences as FP teachers ranged between 9 and 28 years. The criteria for selecting the participants demanded that participants be FP teachers and be speakers of isiXhosa, the mother tongue of the learners. Convenience sampling was followed to choose the sampled schools. All the three schools were easily accessible to the researchers because of their proximity and isiXhosa is the only mother tongue spoken by teachers and learners in schools in that particular district.

\section{Data collection method}

Semi-structured interviews were used by the authors to collect data. In qualitative research, semi-structured interviewing is used because it is open-ended and more flexible, allowing the researcher to probe in order to obtain in-depth data (Nel 2011). The authors used interviews in order to gain insight into the teachers' experiences in using isiXhosa as the medium of instruction in the FP. The interview guide solicited information on how the teachers' training assisted them in teaching in the medium of isiXhosa, how the available material in isiXhosa assisted teachers in the teaching process, what challenges the teachers encounter in teaching Mathematics in isiXhosa, what challenges teachers experience in teaching life skills in isiXhosa and what methods and 
strategies could be put in place in order to make teaching in isiXhosa effective. The interview guide was written in English

\section{Data collection procedure}

The interviews were conducted during the period of September to November 2016 at the respective schools of respondents. We sought, and were granted, permission by the Department of Basic Education to conduct the study. Anonymity, confidentiality and access to the data are the ethical issues that were discussed with the participants before they gave informed consent to participate in the study prior to data collection. Each interview took about $55 \mathrm{~min}$. Permission was also sought from the participants to record the interviews. We used a tape recorder to record the interviews. After transcribing the data, the researchers provided the participants with feedback on the transcriptions of their individual responses to confirm whether the transcriptions were a true reflection of what they had said.

\section{Data analysis}

Content analysis was employed for the analysis of data. According to Silverman (2004), the key tenet of content analysis is that it solicits a relatively systematic comprehensive summary of data. In the current study, recurrent instances were systematically identified and grouped together. Once grouped and analysed, for validation purposes, at least one teacher from each school was requested to confirm the researchers' interpretation of the data solicited from the teachers.

\section{Ethical considerations}

This article followed all ethical standards for a research without direct contact with human or animal subjects.

\section{Results}

Question 1 focused on the relevance of the teachers' professional training with regard to teaching in the medium of isiXhosa. This question was deemed relevant because initial teacher training is likely to have a bearing on how teachers perform in the classroom. The question was further deemed relevant because teachers' professional training involves procedures and provisions designed to equip teachers with the knowledge, attitude, behaviour and skills they require to perform their tasks effectively in the classroom. The respondents in this question had mixed views about their initial training. Although some teachers were of the opinion that their initial training was appropriate to what the current curriculum demanded them to do, other teachers felt that their initial training did not assist them at all towards dealing with the demands of the curriculum. In fact, some teachers revealed that they were not trained at all to teach in the medium of the mother tongue (isiXhosa) but had training in using English as the medium of instruction. Responding to this question, Teacher 5 said:

'If one takes into consideration how the curriculum has changed in South Africa, one would understand that my initial professional training is no longer relevant. I was trained during the time of Primary Teachers' Diploma and although the emphasis was on teaching at the primary level, mother tongue instruction was not emphasised. For, example in teaching Mathematics in the Foundation Phase we used not to translate much into isiXhosa. Learners knew how to count in English from 1 to 10. We took advantage of what they already knew in English and used that as our starting point.' (Teacher 5, female, Grade 1)

Responding to the same question, three teachers out of nine said the following, respectively:

'It does not assist much because I was trained to teach in English. I think our department is of the view that if your mother tongue is isiXhosa you can automatically teach in isiXhosa. That is not true because I battle to teach, especially Maths and Life Skills in is Xhosa.' (Teacher 1, male, Grade 3)

'It does not assist me at all unless the department can provide the necessary support through workshops. But unfortunately, our workshops take only 1 to 3 days, not even a month. That is not enough.' (Teacher 6, female, Grade 1)

'Never trained to teach in isiXhosa.' (Teacher 7, female, Grade 2)

On the same question, Teacher 9 stated the following:

'The focus of my initial professional training was on teaching isiXhosa. I did curriculum studies in isiXhosa. As a result, I find my initial professional training only relevant in teaching isiXhosa. When it comes to teaching Mathematics and Life Skills in isiXhosa, I find my initial professional training irrelevant.' (Teacher 9, female, Grade 3)

Based on the reactions by respondents, it was clear that teachers were not satisfied with the relevance of their initial professional training. To some extent, this may be attributed to the fact that the curriculum in South Africa has changed many times since 1994. Another reason could be that some teachers were trained to teach in English not in isiXhosa. Accordingly, it became clear that a majority of teachers were not equipped with the skills needed to meet the complex demands of teaching course-specific subjects using the medium of isiXhosa.

The second question required teachers to explain if the available material in isiXhosa was of assistance to them in teaching in the medium of isiXhosa. This question was important because learning materials can significantly increase learner achievement by supporting their learning and consequently enhance their academic success. Therefore, an inquiry on the availability of material in isiXhosa and the extent to which such material assists in the learning and teaching process was in order. Respondents' reactions were mixed in this regard. Some respondents indicated that while some material was available, it was not adequate and, therefore, did not assist them much. Others indicated that 
they were happy with the available material and that it added value or supported them when they presented their lessons. The respondents also highlighted the fact that although the materials, like charts were available, they were still written in English. They also pointed out that having access to material in isiXhosa without training on how to use it was not good enough. Hereunder follows some verbal quotes from the respondents with regard to availability and usefulness of the teaching material:

'Not enough material, teaching aids previously were available in English. You could buy them anywhere. But now it is difficult to find teaching aids written in isiXhosa.' (Teacher 1, male, Grade 3)

'It assists in building vocabulary e.g. songs, rhymes, poems, topics and pictures.' (Teacher 2, female, Grade 2)

'A bit not much.' (Teacher 3, female, Grade 1)

'It makes my job easy and increases learners' understanding of concepts by providing learners with real material/objects.' (Teacher 4, female, Grade 3)

'The material is not enough.' (Teacher 5, female, Grade 1)

'It assists a lot, especially the DBE [Department of Basic Education] workbooks.' (Teacher 6, female, Grade 1)

'Material is always never enough.' (Teacher 7, female, Grade 2)

'To a small extent.' (Teacher 8 , female, Grade 1)

'The material without training will not help.' (Teacher 9, female, Grade 3)

The above statements clearly reveal the desperation of the teachers to have the relevant material that would assist them. Judging from their plight, one would imagine what is taking place in the respective teacher' classrooms with regard to learning and teaching. It is clear that their classroom practice is not what they prefer. Rather, they have to cope and deal with existing circumstances that dictate their classroom practice.

The third question focused on the challenges teachers encounter in teaching Mathematics in isiXhosa. As all the respondents had isiXhosa as their mother tongue, it was important to know how they managed to teach a subject that is scientifically developed in the medium of their mother tongue (isiXhosa). The results demonstrate that teachers faced many challenges in teaching Mathematics using isiXhosa as the medium of instruction. Their problems emanated from having to translate concepts of mathematics from English to isiXhosa. Even those who were using material that was written in isiXhosa were experiencing challenges because of the fact that the vocabulary that was used was not user friendly to the learners. They explained that the isiXhosa that learners speak at home is mixed with other languages like English and Afrikaans while the isiXhosa used in the learning materials is old isiXhosa that is no longer in contemporary everyday use for communication in their communities. Some respondents mentioned that some isiXhosa vocabulary that was used in the translated material was foreign to the learners. In response to this question, teachers mentioned the following points:
'The way to pronounce and spell the Maths in isiXhosa is difficult for learners and I find it difficult to translate some Mathematics concepts/terms into isiXhosa. Some words are not isiXhosa but have been borrowed from other languages. Therefore, learners find it difficult to express themselves because they lack isiXhosa vocabulary that is related to Mathematics.' (Teacher 2, female, Grade 2)

Responding to the same question, Teacher 6 said:

'Learners do not understand Mathematics in isiXhosa. As a teacher, I experience problems in understanding the Mathematics concepts that are translated to isiXhosa. How much more with the learners? As a result, I am forced to do codeswitching. For example, the isiXhosa words are so long. Like 'zintandathu' for six. Therefore counting in isiXhosa becomes problematic for the learners. When these learners come to school, they already know how to count from 1 to 10 and when they come to school we seem to take them back to the language they do not use daily or even understand.' (Teacher 6, female, Grade 1)

The following is the response from Teacher 8:

'Learners encounter spelling problems when using isiXhosa as they find it easy to write five but difficult to write 'Zintlanu' which is isiXhosa translation for five. Another example is that of seven and 'zisixhenxe' which the isiXhosa version of seven is. In such cases, learners tend to answer in English whilst you are teaching them in isiXhosa. They seem to prefer English vocabulary to isiXhosa vocabulary when it comes to Mathematics.' (Teacher 8, female, Grade 1)

Responding to the same question, Teacher 1 said:

'Learners tend to use English terms because they know the numbers in English even before they come to school. In Mathematics I always try code switching but that also won't succeed as there are terms which need English and that is another challenge. Being unable to interpret all Maths terms to isiXhosa frustrates me. I think the lack of isiXhosa Mathematics vocabulary or Mathematics terms and terminology is a major problem. Another example is that learning about a clock in isiXhosa language is difficult for the learners but they find it easy in English.' (Teacher 1, male, Grade 3)

This is how Teacher 4 responded:

'Learners struggle to read aloud difficult sounds like nx, ngq in isiXhosa whereas English becomes better. It is difficult to explain numbers, shapes and other mathematical words in isiXhosa. Even in our communities, there are few people who understand how to call thousands, rands and cents in isiXhosa. It takes a lot of time to explain because children go to school having acquired skills in numbers. There is no nye, mbini ntathu etc. Another example with colours, for example, umthubi or tyheli. In English yellowish is yellow. Another example is mboxobuxande [rectangle] is too long. That is not used in everyday language. Therefore there in no continuity.' (Teacher 4, female, Grade 3)

'Some words are very difficult to translate to Xhosa, e.g. cone, cylinder [3D \& 2D shapes].' (Teacher 4, female, Grade 3) 
The foregoing responses provide evidence that teaching in isiXhosa was difficult for some teachers. In some cases teachers relied on their own translation. This could be problematic as these teachers were not trained translators. It would be easy for them to send different messages to the learners because of language distortion in the process of translation. The researchers observed that the teachers were not aware that dictionaries covering the entire primary phase of Science and Mathematics exist.

Part two of the third question focused on the challenges teachers encounter in teaching life skills in isiXhosa. Similar to mathematics, the respondents complained that it was difficult for learners to understand some isiXhosa words. This was also a problem for some educators as they felt that the isiXhosa translation of some words was not in isiXhosa but in isiZulu. Teachers felt that the isiXhosa vocabulary that was not used in everyday communication was problematic. Reacting to this question Teacher 5 said:

'Translation of material from English to various indigenous languages is done by National government. Sometimes you doubt if the translator was an isiXhosa speaker. However, Life Skills is better than Mathematics because of the outdoor activities that excite learners and in that way, learning takes place without relying solely on the language.' (Teacher 5, female, Grade 1)

Responding to the same question, Teacher 3 said:

\begin{abstract}
'Translation sometimes becomes a problem. For example, there are animals that do not have isiXhosa names e.g. octopus. In addition, learners do not understand some Xhosa words, e.g. amandongomane for peanuts. For learners, the English language is easier than isiXhosa. E.g. hare instead of umvundla. Although I try to codeswitch, I still find it difficult to explain and translate other words and topics. In other words, isiXhosa vocabulary is strong in some cases and there are names that do not have a direct isiXhosa translation.' (Teacher 3, female, Grade 1)
\end{abstract}

The above information reveals that teaching life skills was similar to teaching mathematics because both subjects demanded teachers to translate from English to isiXhosa and vice versa. The situation was also aggravated by wrong isiXhosa translation in some textbooks. Another challenge was that teachers were focussing on the direct translation of the text. They were expecting a situation where the source language is mirrored word for word into the target language and yet the focus should be on the overall meaning of the text.

The fourth question focused on the methods and strategies that could be put in place in order to make teaching in isiXhosa effective. Responding to this question, teachers were of the view that having teaching aids written in isiXhosa could support learning and teaching in isiXhosa. They also felt that having mathematics dictionaries in isiXhosa would partly solve their challenges. Some teachers felt that having isiXhosa textbooks would save them from the translation process. Above all, teachers mentioned that training on how to teach mathematics and life skills using isiXhosa would assist them. They suggested workshops to be organised for the FP teachers by the Department of Education. Teachers also recommended the use of codeswitching in the FP. Instead of relying on translation from English to isiXhosa and vice versa, teachers were also of the view that they should be allowed to use both languages freely without translation. Hereunder is how some teachers responded to this question:

'In order to master isiXhosa learners must have enough teaching aids in isiXhosa language so that learners are able to study on their own.' (Teacher 1, male, Grade 3)

'Resources in isiXhosa to be used.' (Teacher 9, female, Grade 3)

'Teachers should always speak the correct isiXhosa language and encourage learners to speak as much isiXhosa as possible even at home.' (Teacher 2, female, Grade 2)

'Translation of the terminology in isiXhosa i.e. Mathematics isiXhosa dictionaries. 'There should be supporting material to support the learners in the learning of isiXhosa.' (Teacher 4, female, Grade 3)

'Learners to use Xhosa textbooks so that teachers do not have to translate.' (Teacher 6, female, Grade 1)

'To train teachers on how to teach using isiXhosa e.g. government conducting more than a month training workshops for the Foundation Phase teachers.' (Teacher 7, female, Grade 2)

Concerning the methods and strategies that could be used in order to teach effectively in the medium of isiXhosa, the respondents were of the view that pre-service and in-service training in teaching in isiXhosa would assist them. One respondent even complained about the duration of the workshops conducted by the government that normally takes 1-3 days. It is the respondent's view that such short workshops are unlikely to assist the FP teachers in enhancing their skills in teaching using the mother tongue as the means of communication, a skill these teachers need the most. It is imperative to note that even if teachers themselves have isiXhosa as their mother tongue, they still lack much needed knowledge in isiXhosa pedagogy.

\section{Discussion of findings}

What has emerged from this study is that teachers were not satisfied with the relevance of their initial professional training. Specifically, teachers who participated in the study all indicated that they were not trained to use African languages (isiXhosa) as a medium of instruction across the curriculum. Such a reality faced by these teachers is reinforced by Benson (2004) when arguing that without specific training on multilingual strategies and a practice, instruction in the learners' mother tongue is likely to be ineffective. This finding further coincides with Valerio's (2015) study on mother tongue based-multilingual education (MBT-MLE) conducted in the Philippines whose results, among others, indicated that training on mother tongue based instruction was necessary for teachers in order to implement the curriculum that demands mother tongue based instruction. Buttressing the importance of teacher training, Dutcher (2004) argues that most teachers need training in methodology so that they can exploit the advantages of teaching in the 
language that children can understand. It is also interesting to note that findings of the current study present evidence of teachers' negative feelings about their initial professional training, something that stands in contradiction to Hobson et al.'s (2006) study. In their study, Hobson et al. observed that the majority of teachers felt positive about the support they received during their initial professional training even though those trained to teach in primary schools gave lower ratings than those trained to teach in secondary schools. An ineluctable deduction made from this study is that primary teachers are more prone to finding their initial professional training unsuitable for their practice.

The results also revealed that material written in isiXhosa was not sufficient and, in some cases, not available at all. This finding confirms results of a study by Afolabi et al. (2006:36) which concluded that 'teaching can only be effected when adequate and relevant instructional materials are used'. A similar observation was also made by Valerio (2015) wherein teacher respondents emphasised that they needed textbooks and dictionaries in the mother tongue to accommodate the needs of learners and to successfully implement the MTB-MLE. Valerio's respondents further pointed out that the lack of books written in the mother tongue affects teaching and learning activities. Malone (2007) emphasises the importance of the availability of material in the mother tongue by contending that literacy in the mother tongue can only be maintained if there is adequate supply of reading material in the mother tongue. Adding on the significance of having materials in the mother tongue, Dutcher (2004) maintains that materials, in the mother tongue, have to be appropriate, available and interesting to the learners.

Another important finding of the study further revealed that teachers experienced several challenges with regard to mathematics when using isiXhosa as a medium of instruction. Most of the challenges highlighted by teachers largely emanated from translating concepts of mathematics from English into isiXhosa. Of interest, and worth noting, is that even teachers who used material written in isiXhosa complained that the vocabulary used was not user friendly to learners. The foregoing observation is in tandem with Mashegoane's (2017) view when posing that the inability of hundreds of languages around the world who do not have direct translations of core scientific and mathematic terms is a hindrance for learning. While a counter-argument can be made advancing the need for these languages developing more learner-friendly and contextually relevant terminology or borrowing, Foley's argument remains valid in that it points out to a disjuncture between language development and language rights, something that should be a subject of a different study other than the current one. It is not lost to the researchers that in so far as the usefulness of the mother tongue in the teaching and learning of mathematics, the results of the present study contradict the results of a study conducted by Mufanechiya and Mufanechiya (2011) in Zimbabwe. In their study, the Mufanechiyas focused on the use of the mother tongue as a medium of instruction in the mathematics classroom in the junior secondary schools. Their findings revealed that teachers and learners found mother tongue vocabulary useful, learner-friendly and helpful in the teaching of mathematics. Mirrored against the current study, it is easy to attribute the Mufanechiyas' study results on the nature of the mother tongue with regard to its level of development and/or its possible closeness to the English language, over and above the difference in the phases or levels the two studies focus on.

As regards the proffering of methods and strategies that could be implemented to make teaching in isiXhosa effective, the findings of the study revealed that most teachers recommended codeswitching and translation of support material into isiXhosa. This finding confirms earlier research conducted by Jegede (2011) in Nigeria which revealed that the use of codeswitching in multilingual mathematics classroom does not result in a deficiency in learning, but is a useful strategy in classroom interaction and an efficient way of transferring knowledge to learners. This finding is also supported by Cummins (2000) who observed that in the course of learning one language a child acquires a set of skills and implicit metalinguistic knowledge that can be drawn upon when working in another language. In other words, conceptual knowledge developed in one language helps to provide input for comprehension in the other language. From a South African perspective, the finding is also in consonance with Setati's (2008) study, which also proffers codeswitching as a viable tool, which can provide spontaneous and reactive discussion of concepts by learners and teachers in their mother tongue. As far as the translation of material from English to isiXhosa is concerned, the results of another study by Setati, Molefe and Langa (2008) support such a move. However, the researchers also observed that, in some instances, learners found the translation of mathematical terms into the local language by their teacher difficult to understand. Attesting to this reality, Schafer (2010) who also conducted a study among FP isiXhosa speaking teachers in the Eastern Cape observed that a number of teachers felt that the isiXhosa that was used in the resource book was at times difficult to understand. Schafer (2010:513) further revealed that teachers were of the view that the "translations were dominated by "deep" isiXhosa, sometimes referred to as rural, old and traditional as opposed to everyday or modern isiXhosa'. Also attesting to this reality, Kazima (2008:62) argues that mathematical terms have precise meanings, which are not easy to capture in one word in many African languages and, in such instances, Kazima suggests that some mathematical terms might be best presented in their English form.

\section{Conclusion}

In this article, the authors have raised a number of issues pertaining to instruction in mother tongue in the FP, specifically focussing on teachers' experiences in teaching 
learners using isiXhosa as a medium of instruction. IsiXhosa as a medium of instruction was chosen because it is one of the indigenous languages recommended for use in South Africa's language-in-education policy. In the process of collecting data it became evident that a majority of FP teachers had not received training to teach content-specific subjects through the medium of isiXhosa. Ultimately, they have had to improvise in an attempt to facilitate learning in their respective classrooms. Such lack of training in using isiXhosa as a medium of instruction raises serious questions on how teacher education programmes, pre-service as well as in-service, can possibly recognise the value of, and need to foreground, indigenous languages as important languages that should contribute to effective teaching and learning. The study also revealed that teachers encountered numerous challenges in teaching mathematics and life skills in isiXhosa. Some of the challenges emanated from the lack of isiXhosa vocabulary to match terms or concepts related to mathematics and life skills, which compelled teachers to attempt translating from English into isiXhosa. However, the appropriateness of the translation remains a persistent challenge because teachers are not trained in translation. The researchers were of the view that the teachers were not aware that the isiXhosa dictionary for Science and Mathematics exists for the primary phase. Given the aforementioned realities, respondents resorted to the use of various teaching strategies, which include, but are not limited to, codeswitching and use of multiple educational media or learner support material in order to enhance the facilitation of learning. The results further identified a shortage of learner support material written in isiXhosa and this necessitates that teachers also be trained on how they can develop their own material in isiXhosa taking into account the FP learners' background and context. It is the present writers' view that any such material produced should take into consideration; not only the learners' mother tongue but their experiences as well. These can be used to motivate learners in teaching and learning activities as they would be able to contextually relate to such material.

\section{Recommendations}

The researchers recommend that teacher training institutions in South Africa should provide adequate and relevant preand in-service and training courses on the pedagogy of teaching in the FP learning areas in isiXhosa to ameliorate teachers' insufficient initial professional training to teach in isiXhosa. This could further be achieved through government's intervention by offering bursaries for student teachers specialising in African languages like isiXhosa. In those courses, students should be taught how to use isiXhosa as the medium of instruction for the entire FP curriculum. Material for the entire FP curriculum at the institutions of higher learning should be translated into isiXhosa to prepare pre-service teacher trainees on what to expect in the FP classrooms. Universities should also play an important role in retraining the in-service teachers and the Department of
Basic Education should encourage and assist the in-service teachers to enrol for a continuous in-service training course that should not last less than a year. The content of such a course should equip in-service FP teachers with the necessary skills to teach in the medium of isiXhosa. In-service teachers could utilise their weekends and school holidays to attend lectures. Staff of training institutions should visit, monitor and support these teachers in their respective schools to, among others, eliminate any challenges regarding the implementation of the course content. The researchers recommend that the Department of Basic Education should provide incentives to teachers who complete the course. This course should be made compulsory for all FP teachers by giving them a certain number of years within which they are expected to complete the course.

We further recommend that all textbooks, readers, educational media, study guides and related literature be made available in isiXhosa. The researchers are of the view that if the learner support material is readily accessible in the learners' language, it is likely to lessen the burden of translation by teachers and this will, ultimately, ensure that all learners in various schools receive a similar message. Codeswitching as a teaching strategy is recommended. Accordingly, teachers should be allowed to use English concepts because even learners are familiar with those English terms from within their environment. The adoption of codeswitching as a teaching strategy should be for a short-to medium term while more appropriate terminology in isiXhosa is being developed as a long-term solution. It is imperative to note that temporary reliance on codeswitching should not hinder the opportunity for isiXhosa to be developed as a language of instruction. As a long-term goal, teachers, with the assistance of the Department of Basic Education, should come together and develop a mathematics register in isiXhosa with the assistance of trained terminologists and lexicographers. With regard to life skills, the findings of the study indicated that learners comprehend better when the information presented orally is accompanied by performance. Therefore, the authors recommend that life skills educators should accommodate different learning styles in their classrooms. If teachers are aware of their learners' learning styles they will be in a better position to design classroom activities that do not only rely on oral information in order to cater to visual learners and kinaesthetic learners.

\section{Acknowledgements Competing interests}

The authors declare that they have no financial or personal relationships, which may have inappropriately influenced them in writing this article.

\section{Authors' contributions}

M.M. took the initiative to conduct the study. He also conceptualised the title of the manuscript, collected and analysed the data. T.M. was responsible for the methodology 
section and wrote the first draft of the manuscript. M.C. was responsible for the discussion and findings. He put together the final draft and edited the manuscript.

\section{Funding information}

This research received no specific grant from any funding agency in the public, commercial or not-for-profit sectors.

\section{Data availability statement}

Data sharing is not applicable to this article as no new data were created or analysed in this study.

\section{Disclaimer}

The views and opinions expressed in this article are those of the authors and do not necessarily reflect the official policy or position of any affiliated agency of the authors.

\section{References}

Afolabi, A.O., Adeyanju, O.L., Adedapo, Y.A. \& Falade, A.A., 2006, 'Preparation and use of simple instructional materials', European Journal of Scientific Research 8(1), 67-87.

Ball, J., 2008, 'Aboriginal young children's language and literacy development: Progress, promising practices, and needs', in Encyclopedia of language literacy development, Canadian Language and Literacy Research Network, London, ON National Literacy Strategy Initiative, viewed 17 March 2018, from http://www. literacyencyclopedia.ca/pdfs/topic?topld=257.

Begi, N., 2014, 'Use of mother tongue as a language of instruction in early years of school to preserve the Kenyan culture', Journal of Education and Practice 5(5),
$37-49$.

Bender, P., Dutcher, N., Klaus, D., Shore, I. \& Tesar, C., 2005, In their own language? Education for all, Education Notes Series, World Bank, Washington DC,
viewed 03 January 2018, from http://documents.worldbank.org/curated/en/ viewed 03 January 2018, from http://documents.worldbank.
374241468763515925/In-their-own-language-education-for-all.

Benson, C., 2004, 'Bilingual schooling in Mozambique and Bolivia: From experimentation to implementation', Language Policy 3, 47-66. https://doi. org/10.1023/B:LPOL.0000017725.62093.66

Bromley, D.B., 1990, 'Academic contributions to psychological counselling: In a philosophy of science for the study of individual cases', Counselling Psychology Quarterly 3(3), 299-307. https://doi.org/10.1080/09515079008254261

Chihana, V. \& Banda, D., 2013, 'The nature of challenges teachers face in using Malawi breakthrough to literacy MBTL course to teach initial literacy to standard one learners in Mzuzu, Malawi', viewed 14 February 2018, from https://sitwe. wordpress.com/2013/07/27/the-nature-of-challenges-teachers-face-in-usingthe-malawi-breakthrough-to-literacy-mbtl-course-to-teach-initial-literacy-tostandard-one-learners-in-mzuzu-malawi/.

Colliers, V.P. \& Thomas, W.P., 2004, 'The astounding effectiveness of dual language education for all', NABE Journal of Research and Practice 2(1), 1-20.

Cummins, J., 1989, 'Language and literacy acquisition in bilingual contexts', Journal of Multilingual and Multicultural Development 10(1), 17-31. https://doi.org/10.108 0/01434632.1989.9994360

Cummins, J., 2000, Language, power, and pedagogy: Bilingual children in the crossfire, pp. 31-53, Multilingual Matters Ltd., Tonawanda, NY.

Dutcher, N., 2004, Expanding educational opportunity in linguistically diverse societies, Center for Applied Linguistics, Washington DC, viewed 17 March 2018, from https://eric.ed.gov/?id=ED466099.

Foley, A., 2015, 'Mother-tongue education in South Africa', Teaching English Today, viewed 22 March 2018, from https://teachenglishtoday.org/index.php/2010/06/ viewed 22 March 2018, from https://teachen

Gacheche, K., 2010, 'Challenges in implementing a mother tongue-based language-ineducation policy: Policy and practice in Kenya', POLIS Journal 4, 1-45.

Hobson, A.J., Malderez, A., Tracey, L., Giannakaki, M.S., Pell, R.G., Kerr, K. et al., 2006 Becoming a teacher: Student teachers' experiences of initial teacher training in England, Research Report RR 744, The University of Nottingham, Nottingham.

Jegede, O., 2011, 'Code switching and its implications for teaching Mathematics in primary schools in Ile-lfe, Nigeria', Journal of Education and Practice 2(10), 41-55.

Kazima, M., 2008, 'Mother tongue policies and mathematical terminology in the teaching of mathematics', Pythagoras 67, 56-63. https://doi.org/10.4102/ pythagoras.v0i67.74

Kuper, W., 2003, 'The necessity of introducing mother tongues in education systems of developing countries', in A. Ouane (ed.), Towards a multilingual culture of education, pp. 89-102, UNESCO Institute for Education, Hamburg.
Mackenzie, P.J. \& Walker, J., 2013, 'Global campaign for education policy brief', in Mother tonque education: Policy lessons for quality and inclusion, Johannesburg, viewed 24 March 2018, from www.campaignforeducation.org.

Makeleni, N.T. \& Sethusha, M.J., 2014, 'The experiences of foundation phase teachers in implementing the curriculum', Mediterranean Journal of Social Sciences 5(2), 103-109. https://doi.org/10.5901/mjss.2014.v5n2p103

Malone, S., 2007, 'Mother tongue-based multilingual education: Implications for education policy', SIL International, Unpublished PhD thesis, University of Zimbabwe.

Malone, D. \& Malone, S., 2011, 'Teacher education for mother tongue-based education programmes', SIL International, pp. 1-15, viewed 03 February 2018 from http://www.sil.org/.../institutionalizing_teacher_training_for_mtb_mle_122011pdf.

Martin, P.W., 2005, 'Safe language practices two rural schools in Malaysia: Tensions between policy and practice', in A.M.Y. Lin \& P.W. Martin (eds.), Decolonisation Globalisation: Language-in-education, policy and practice, pp. 74-97, Multilingual Matters, Clevedon.

Mashegoane, P., 2017, 'Fallacy of teaching Maths and Science in mother tongue', THE BLOG, viewed 13 January 2018, from https://www.huffingtonpost.com/.. mashegoane/fallacy-of-teaching-maths_b_118653....

Matjila, D.S. \& Pretorius, E.J., 2004, 'Bilingual and biliterate? An exploratory study of Grade 8 reading skills in Setswana and English', Per Linguam 20, 1-21. https://doi. org/10.5785/20-1-77

Mufanechiya, A. \& Mufanechiya, T., 2011, 'Using mother tongue as a medium of instruction in the teaching of Mathematics in the Zimbabwean junior primary schools: Desirable or feasible?', Journal of Asian Scientific Research 1(4), 194-203.

Murray, C., 2007, 'Reflections on the question of mother tongue instruction in Namibia', NAWA Journal of Language and Communication 69-77, viewed 11 April 2018, from http://ir/wst.na/bitstream/hanlde/0628/120/Murray.

Muthivhi, A.E., 2008, 'Socio-cultural case study of the schooling system in Venda, South Africa', Unpublished doctoral thesis, University of the Witwatersrand.

Nel, C., 2011, 'Linking reading literacy assessment and teaching: Rethinking preservice teacher training progress in the foundation phase', Journal for Language Teaching 45(2), 9-30.

Njoroge, M.C., 2017, 'The efficacy of using mother tongue language in the teaching of mathematics and science in primary schools: Evidence from grade one classrooms in Kenya', Journal of Applied Linguistics and Language Research 4(8), 133-150.

Obanya, P., 2004, 'Learning in, with, and from the first language', PRAESA Occasional Papers 19, 1-30.

Parry, O., 2000, Male underachievement in high school education in Jamaica, Barbados and St Vincent and the Grenadines, Canoe Press, Kingston.

Prah, K.K., 2009, 'Mother-tongue education in Africa for emancipation and development: Towards the intellectualisation of African languages', in B. BrockUtne \& I. Skattum (eds.), Languages and education in Africa: A comparative and transdisciplinary analysis, pp. 83-104, Symposium Books, Oxford.

Schafer, M., 2010, 'Mathematics registers in indigenous languages: Experiences from South Africa', in L. Sparrow, B. Kissane \& C. Hurst (eds.), Shaping the future of mathematics education: Proceedings of 33rd annual conference of the Mathematics Education Research Group of Australasia, pp. 509-514, MERGA, Fremantle.

Setati, M., 2008, 'Access to mathematics versus access to the language of power: The struggle in multilingual mathematics classroom in South Africa', Educationa Studies in Mathematics 42(3), 243-269.

Setati, M., Molefe, T. \& Langa, M., 2008, 'Using language as a transparent resource in the teaching and learning of mathematics in a Grade 11 multilingual classroom', Pythagoras 67, 14-25. https://doi.org/10.4102/pythagoras.v0i67.70

Silverman, D., 2004, Qualitative research: Theory, method and practice, 2 nd edn., Sage, London.

Slavin, R.E., 2008, 'What works? Issues in synthesising educational programme evaluations', Educational Research 32, 5-14. https://doi.org/10.3102/ 0013189X08314117

Smit, B., 2001, 'How primary school teachers experience education policy change in South Africa', Perspectives in Education 19(3), 67-83.

Smits, J., Huisman, J. \& Kruij, K., 2008, Home language and education in the developing world, UNESCO, viewed 16 February 2018, from http://unesdoc.unesco.org/ images/0017/001787/178702e.pdf.

Trudell, B., 2005, 'Language choice, education and community identity', International Journal of Educational Development 25, 237-251. https://doi.org/10.1016/j. ijedudev.2004.08.004

UNESCO, 2006, 'Challenges of implementing free primary education in Kenya: Assessment report', viewed 12 April 2017, from http://unesdoc.unesco.org/ images/001516/151654eo.pdf.

UNESCO, 2007, Mother tongue-based literacy programmes: Case studies of good practice in Asia, UNESCO, Bangkok..

UNESCO, 2011, Enhancing learning of children from diverse language backgrounds: Mother tongue-based bilingualism or multilingual education in the early years: Literature review, UNESCO, Paris, viewed 22 March 2018, from http://www. unesco.Org/en/languages-in-education/publications/.

UNICEF, 2011, Action research on mother tongue-based bilingual education: Achieving quality, equitable education, viewed 17 January 2018, from http://www.vn.one. un.org. 
Valerio, M.T.B., 2015, 'Current perspectives on mother tongue-based instruction in the newly implemented $\mathrm{K}$ to 12 curriculum of the Philippines', British Journal of Education 13(9), 51-66.

Wigglesworth, G. \& Simpson, J., 2008, 'The language learning environment of preschool children in indigenous communities', in S. May (ed.), Critical multiculturalism: Rethinking multicultural and antiracism education, pp. 13-29, Falmer Press, London.
World Bank, 2005, In their own language...Education for all, World Bank, Washington DC, viewed 27 February 2018, from http://siteresources.worldbank.org/ EDUCATION/Resources, Education-Notes/EdNotesLangoflnstruct.pdf.

Young, C., 2009, 'Good practices in mother tongue - First multilingual education', in M. Redmond (ed.), Mother tongue as bridge, language instruction: Policies and experiences in Southeast Asia, pp. 120-135, The Southeast Asian Ministers of Education Organization (SEAMEO) Secretariat, Bangkok. 